\title{
THE PHILOSOPHICAL INITIATION in Plato's PHAEDRUS
}

\author{
Kazimierz Pawlowski \\ Cardinal Stefan Wyszynski University (Warsaw) \\ k.pawlowski@uksw.edu.pl
}

\begin{abstract}
The article deals with the topic of "initiations" in Plato's Phaedrus. The idea of initiation was characteristic of Greek mysteries, especially the Eleusinian and Orphic mysteries, which played a large role in the formation of Greek philosophy. The essence of initiations was the experience of divinity. The motive of initiations in Plato's Phaedrus seems to have a similar meaning. This is also suggested by the allegory of human souls as chariots and the mystical "epopteia" motif woven into it, suggesting Eleusinian analogies. KeYwORDS: Plato, Socrates, Phaedrus, philosophical initiation, madness of Eros, myth.
\end{abstract}

\section{Written word and philosophy}

Phaedrus is, without doubt, not only one of Plato's most beautiful dialogues but also one that is particularly inspiring. It has been called "un dialogo cruciale" by Giovanni Reale, outstanding Italian Plato scholar and translator (in: Gaiser 1996, $14)^{1}$ - and indeed its influence on our understanding both of philosophy and of

${ }^{1}$ Cf. also: Cf. also: Cerri G., 1991, pp. 77-92; Erler M., 1991, pp. 77-92; Głogowska A., 20o6, 23-35; Kahn C.H., 1996, pp. 371-392; Szlezak T. 1997, pp. 52-6o; Trabattoni F., 2005, pp. 8698; Vegetti M., 201=227, pp. 201-227; Yunis H., 2015, pp. 101-125. Reale G., 1998, pp. 101-114; Yunis H., 2015, pp. 105-109. According to Harvey Yunis Phaedrus was written between 380 and $360 \mathrm{BC}$, when Athens was recuperating after a political and cultural disruption brought upon it by the Peloponnesian war. Those were the times of famous and influential sophists such as Gorgias, Protagoras and Thrasymachus whose rhetoric achieved great successes, particularly in the world of politics. It is in opposition to them that Plato proclaims in Phaedrus that philosophy is superior to sophistry and that this superiority is,

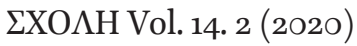

(C) K. Pawlowski, 2020 www.nsu.ru/classics/schole DOI:10.25205/1995-4328-2020-14-2-419-430 
the way we do it may be considered decisive. In the final part of the dialogue Plato (Plato's Socrates) debates the notorious issue of how to value the practice of writing, and, in particular, of writing philosophy. In comparison with the spoken, living word, writing is just a past-time. It is only the living word that may move the student's soul (Plato, Phaedrus, 274 B-278 E). ${ }^{2}$ However this power belongs only to the word uttered by a teacher who possesses knowledge:

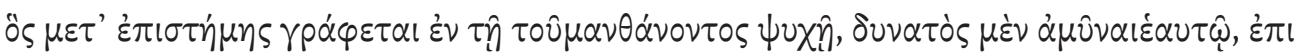

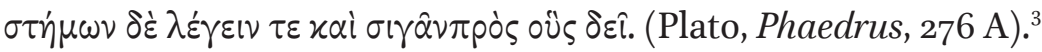

No written word can boast such properties. Written words are just like the famous "gardens of Adonis," planted by farmers during festivals, partly to check the seed quality, partly for idle play (Plato, Phaedrus, 276 B. Cf. Szlezak 1997, 55-57; Baudy 1986). As we know, although Plato himself was a prolific writer, he still favoured the spoken word. Why? Because it is only to the living word that we may entrust philosophy. Of course it could not be just any speech - it has to be one that, imbued with true light, can touch the innermost strings of the philosopher's soul and prepare it to experience the world of supernatural values, the realm of things that are verily Beautiful, Just and Good.

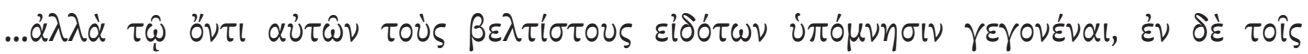

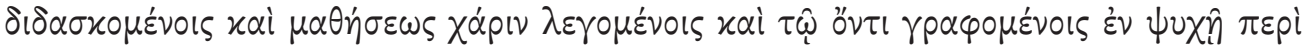

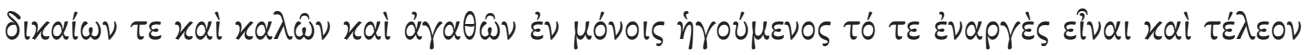

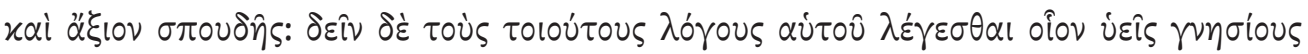

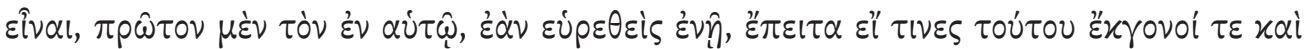

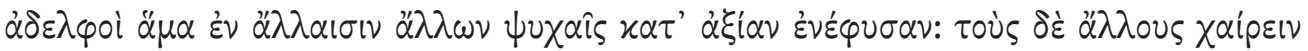

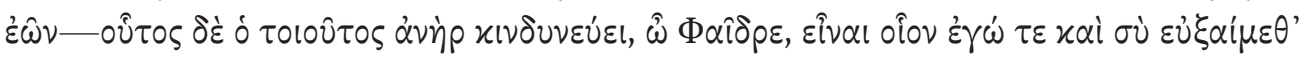

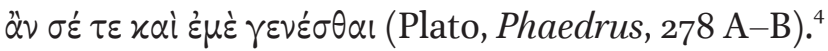

in fact, natural, stemming from the fact that philosophers follow gods in search for the truth while sophists pursue success and applause of the people.

${ }^{2}$ Cf. Platon, Phaedrus, 274 B - 278 B; Epistulae, II 314 C; VII 341 C, 344 C.

${ }^{3}$ Plato, Phaedrus, 276 A: "The word which is written with intelligence in the mind of the learner, which is able to defend itself and knows to whom it should speak, and before whom to be silent." (Trans. H. Fowler).

${ }^{4}$ Plato, Phaedrus, 278 A-B: "...and who thinks that only in words about justice and beauty and goodness spoken by teachers for the sake of instruction and really written in a soul is clearness and perfection and serious value, that such words should be considered the speaker's own legitimate offspring, first the word within himself, if it be found there, and secondly its descendants or brothers which may have sprung up in worthy manner in the souls of others, and who pays no attention to the other words, - - that man, 
If we examine this fragment in the context of the whole dialogue, and especially with the famous vision of souls as chariots in mind (which is a subject that will yet be touched upon here), it is relatively straightforward what kind of speeches and what type of light are being referenced. What is meant is something that undeniably takes its origins in the soul. However, as the soul belongs to the realm of the supernatural, nothing may be begotten there without a particular relationship with the supernatural, a relation appropriate for the soul. Relationships of this kind always develop beyond the level of rationality and thus, essentially, without any words. The relation with the realm of the supernatural which befits the soul is the existential experience, the existential feeling of the supernatural (cf. Plato, Symposium, 210A - 212 A; Plato, Epistulae, 341 C. Cf. Albert 1980, $\left.5{ }^{2-53} ; 67-71\right)$. Any external word can only serve to rouse the soul and, to be more precise, to excite its natural dispositions which include moral and spiritual sensitivity. Among all that takes place in the soul, the most important and significant are the existential spiritual experiences which transcend human rationality. (Of course, they are not beyond the control of the mind - the mind always needs to govern all our acts and experiences, lest we fall into mental irrationality and succumb to the power of superstition.)

The proper disposition of the soul, the power that enables it to experience the world of the supernatural is its natural spiritual sensitivity (with which the soul is naturally equipped). It manifests itself as a curious, mysterious longing after that which is as curious and mysterious as the longing itself.

Human spiritual sensitivity may lead us to the realm of the deepest secrets, of existential mysteries, including the greatest of them all: the mystery of human nature and human existence, so intrinsically intertwined with the enigma of human love. Those mysteries cannot be solved even by the most skillful logical deductions, spoken or written alike. Human rationality can only grasp and solve issues that are rational. Existential questions transcend its sphere of expertise. They require another kind of capabilities and senses, such that are not connected strictly to our perception and rationality - namely our spiritual and moral sensitivity. They are also a natural intrinsic part of human nature, though sometimes they may become subdued by the background noise of civilization and culture which is constantly assailing human consciousness with various cultural and civilizational superstitions. The worst danger brought upon us by such superstitions is that in their claims to absolute validity they might attempt to replace our natu-

Phaedrus, is likely to be such as you and I might pray that we ourselves may become." (Trans. H. Fowler). 
ral sensitivity with superstitious dogmas and our natural intelligence and aptitude for reasoning - with algorithms and mental constructs based upon those superstitious beliefs. The first step which is required of us (at least if we aim to attain spiritual and moral maturity and thus also a degree of independence) by platonic and socratic maieutics is to disavow any such cultural and civilizational superstitions which contaminate human consciousness and deaden our natural moral and spiritual sensitivity. Words, even written words may possess the power to begin the process of rousing such sensitivity (let the writings of Plato himself serve as proof of that). However, as it has already been suggested, existential truth, the one that touches upon the deepest secrets of human existence, can only be conceived within the soul in the presence of a lively, existential relationship with the supernatural. No words and no speech, no matter how learned can ever carry out this task. If we may anticipate what will be elaborated upon in the later sections of this paper - it can only be accomplished by love, though only such that reaches the realm of the supernatural. This kind of love, love that originates in supernaturality, may arouse in us that which is the most noble and the most divine and, as a result, make us achieve a godlike (supernatural) status.

\section{Philosophical Initiations}

The way initiations are introduced in Phaedrus is plainly evocative of mysteries or even mysticism. Socrates associates initiations with the madness of Eros (Plato, Phaedrus, 249 C-D), of love, which is sent to us by the gods (Plato, Phaedrus, 244 A $)^{5}$, as all madness always is. The madness of Eros is one of the four most noble kinds of madness sent by the gods (Plato, Phaedrus, $244 \mathrm{~A}-245 \mathrm{~B}$; see also: ibidem, 265 B - C). It is the noblest gift, the "chiefest blessing" (Ibidem, 245 B - C; 249 E). In saying this, Socrates hints at the fact that his theory of love as madness, as divine inspiration (as well as the idea that poetic, prophetic and mystic inspirations are essentially the same kind of madness) is not rational - it is irrational in the sense that it cannot be based on rational premises and defended by logical reasoning. This is why Socrates claims that the witling will disbelieve his proof and, we may add, reject the whole idea of a god who is present and active in the world. However, it will be received by the wise, someone who is in communion with god's wisdom (and therefore touched by the divine madness - cf. Plato, Phaedrus, 245 C).

The concept of philosophical ordinations in Phaedrus emerges in the context of the famous vision of gods in their winged chariots, dashing through the vast-

\footnotetext{
${ }^{5}$ Plato, Phaedrus, 244 A: "... but in reality the greatest of blessings come to us through madness, when it is sent as a gift of the gods." Trans. H. Fowler)
} 
ness of the Universe with Zeus as their leader, followed by a whole army of other spirits, good and bad, and each of the immortal creatures are assigned to the cortege of the god who best suits them. There are human souls among this crowd of ghosts. All of them, including Zeus, are heading to the top of the heavens and then glide to the other side, and on their way they behold all that which according to Socrates cannot be described by any word, the plains of Truth and absolute values. Only gods can regard those realms in tranquility and calmly return to their places of residence. The spirits in the divine corteges - and human souls in particular - fare variously. Some get to the top and are able to glance at the world of truth for a longer or shorter while. Whatever they manage to remember will serve as their spiritual nourishment right till the end of their incarnate life (or rather, of their existence in conjunction with their flesh) and will also fuel the spiritual, moral and intellectual sensitivity of those souls. Other spirits fail to reach the summit and, having seen nothing, lose their wings. Then, ponderous, angry and devoid of memory, they fall to earth. Such souls are not allowed to become reborn in any animal shape. They will have to wait for ten thousand years until their wings are regrown and they are able to once again set off up into the heavens following their gods (Plato, Phaedrus, $248 \mathrm{E}-249$ A). ${ }^{6}$ The souls that managed to see something of the realm of the truth and did not fall to earth, become incarnated in the bodies of different people, each according to its status, which is determined by how much it was able to see. Those that have observed the most are the noblest souls, they are reborn as philosophers and people who devote themselves to beauty, science or love. Others will inhabit the bodies of righteous kings, warriors and rulers, yet another kind of souls will become great entrepreneurs, politicians and traders. The fourth kind of souls will lead the lives of avid gymnasts or doctors. The fifth type shall inhabit the world of prophets and hierophants. The sixth type, much inferior to the first couple of kinds, is the one to which artists and imitators belong, the seventh, even less noble, is that of artisans and farmers, the eighth, which is quite mediocre, includes sophists and speakers and the last, ninth and worst kind of souls is assigned to the tyrants (and their fate is the most dreadful as it means moral and spiritual perdition). This is how souls attain their first life in the flesh. Afterwards each soul will be assigned a second life, either better or worse, depending on how it conducted itself the first time.

It is accidentally revealed here what is Plato's hierarchy of different vocations. His Socrates lists nine types of human souls. The best, the most noble life is that

\footnotetext{
${ }^{6}$ This is the so-called Great Year - all celestial bodies return to their starting point and begin their journey anew. Cf. Plutarch, The Obsolescence of Oracles, 22: „Opportunity to see and to contemplate these things is vouchsafed to human souls once in ten thousand years". (Trans. F. C. Babbitt).
} 
of philosophers, both on earth and after death. It is those souls that after their third millennium - and after choosing philosophical life three times in a row are given wings and allowed to fly away. Socrates does not tell us precisely where they go but we may suspect, that they are headed straight to the gods with whom they shall feast on the sights of the blessed plains of truth. Other souls go on trial after their first life and afterwards according to the ruling either become imprisoned below the surface or are directed to other, less onerous places where they can lead such lives as they deserved during their existence as humans. After a thousand years they shall draw lots again and choose their lives. Some prefer animal incarnations, others - human bodies (Plato, Phaedrus, 246 E-249 B). As humans they have the chance to climb higher, morally and spiritually, to feed on what is left to them of the plains of truth that they had had the opportunity to see while they were happily soaring through the supernatural and absolute realm with the gods. It is right here that Socrates evokes the concept of "being initiated into the perfect mysteries" which is a possibility for those who sustain themselves with the remnants of such blessed, happy sights from the realm of truth and knowledge, seen when their soul walked blissfully among the gods. After initiation the soul forgets about all human concerns, it participates only in what is divine and tastes some of its forgotten happiness. This is why people often scold such a person for being a downright madman - they do not know that god resides in her soul.

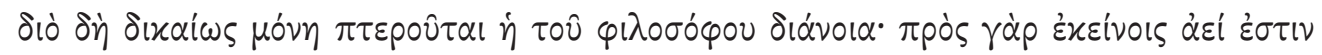

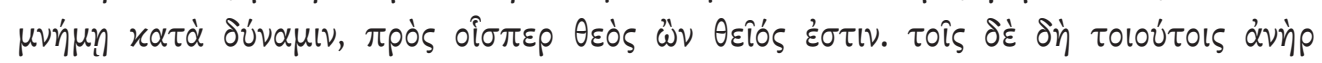

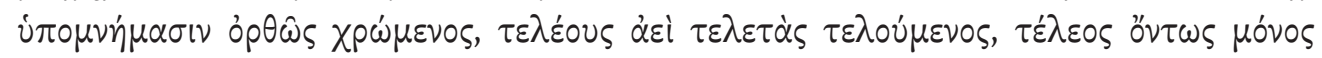

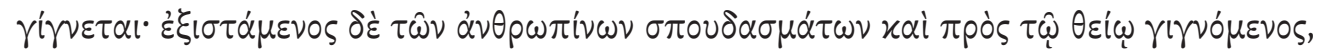

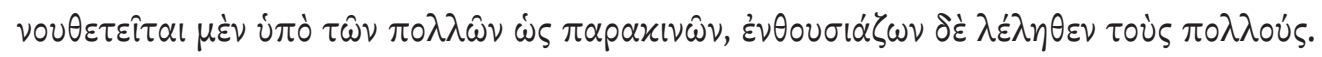
(Plato, Phaedrus, 249 C-D). ${ }^{7}$

It turns out that everything that happens to the philosopher is an effect of the madness of Eros, the noblest of all four kinds of madness which may be experienced by people (and which are always sent by the gods). This last thought is promptly and directly expressed by Socrates:

\footnotetext{
${ }^{7}$ Plato, Phaedrus, 249 C-D: "And therefore it is just that the mind of the philosopher only has wings, for he is always, so far as he is able, in communion through memory with those things the communion with which causes God to be divine. Now a man who employs such memories rightly is always being initiated into perfect mysteries and he alone becomes truly perfect; but since he separates himself from human interests and turns his attention toward the divine, he is rebuked by the vulgar, who consider him mad and do not know that he is inspired". (Trans. H. Fowler).
} 


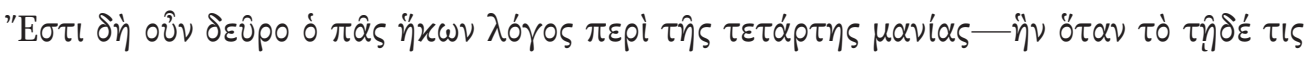

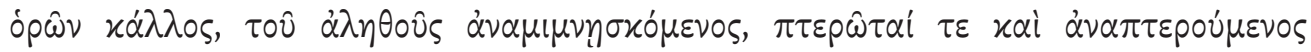

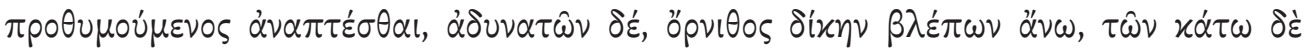

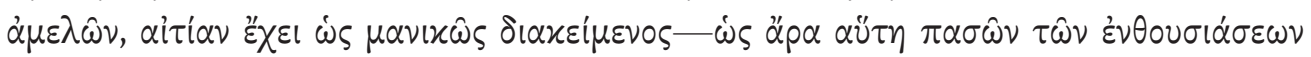

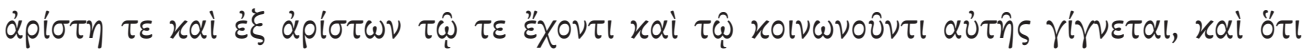

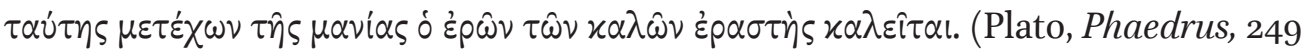
$\mathrm{D}-\mathrm{E}){ }^{8}$

Once again it is stressed that the secret passion that devours the philosopher isolates her from life and forces her to look for something other, a mysterious, divine beauty which she does not yet know nor understand, but which already abides in her soul in some way and attracts her with its exquisiteness, so foreign to this world of matter and earthly bustle. This beauty stems from a divine inspiration, although at the same time it does constitute the natural state of her soul. This is why the philosopher and a lover of beauty is sensitive to all that is beautiful, and particularly what is beautiful in a moral and spiritual way.

The myth described above is, as we may suppose, an allegory of human condition, not only in its moral and spiritual dimension but also in the intellectual one (the desire for Truth is, after all, dominating the philosopher's soul and her memories of this Truth are the essential nourishment for the soul. The different kinds or types of souls (of which Socrates distinguishes no less than nine) reflect their varied degree of sensitivity - above all, their moral sensitivity to moral beauty, but also their intellectual and spiritual understanding of truth and goodness. Sensitivity is, of course, an innate quality, one that we bring with us to this world, and therefore it is natural and essential to the human soul. As is shown by the myth, it is an echo of the supernatural roaming our earthly lives. It directs us towards the absolute and the supernatural. Although it is an innate disposition of the human soul, it does not develop equally well in different people - or rather, it is not equally aroused. This is the reason why we are not equally able to receive and absorb supernatural (ideal) values. Some of us are unable to do it at all and thus they are in a way condemned to a life in the realm of purely material and biological qualities. Others however remain almost constantly spiritually connected to the supernatural plain thanks to their highly aroused sensitivity. This last remark

\footnotetext{
${ }^{8}$ Plato, Phaedrus, 249 D-E : "All my discourse so far has been about the fourth kind of madness, which causes him to be regarded as mad, who, when he sees the beauty on earth, remembering the true beauty, feels his wings growing and longs to stretch them for an upward flight, but cannot do so, and, like a bird, gazes upward and neglects the things below. My discourse has shown that this is, of all inspirations, the best and of the highest origin to him who has it or who shares in it, and that he who loves the beautiful, partaking in this madness, is called a lover". (Trans. H. Fowler).
} 
concerns, of course, mainly philosophers but also those of us who are capable of true love and burn with a magnificent, noble affection towards other people.

This spiritual connection with the realm of truth is what Socrates calls being initiated into perfect mysteries. He associates initiation with perceiving absolute, supernatural - and therefore divine values. This is why Socrates claims that to undergo this kind of ordination is to be inhabited by god himself. Let us remind ourselves that in Phaedo, Socrates speaks in a similar way of philosophers, who devote their whole souls to the love of wisdom (Plato, Phaedo, $69 \mathrm{C}-\mathrm{D}){ }^{9}$

If our analysis is not to be too shallow, reducing the initiation to a unilateral perception of supernatural values grounded solely in innate sensitivities, we need to add, following Socrates' own suggestions, that it is related to some sort of a divine inspiration (Eros' madness, sent by the god). ${ }^{10}$ We may expect to find certain underlying spiritual experiences. Regardless of that, however, we need to remember that initiation is not possible without a strongly developed spiritual sensitivity (as is the case with various arts - it is understandable that without a particular kind

${ }^{9}$ Plato, Phaedo, 69 C-D: "For as they say in the mysteries, 'the thyrsus-bearers are many, but the mystics few'; and these mystics are, I believe, those who have been true philosophers". (Trans. H. Fowler). Initiations are also considered in Gorgias, in the context of Socrates' debate with Callicles and Polos about the fundamental Platonic rule of not causing harm: “...and the thoughtless he called uninitiate: in these uninitiate that part of the soul where the desires are, the licentious and fissured part, he named a leaky jar in his allegory, because it is so insatiate." (Plato, Gorgias, 493, trans. W. R. M. Lamb).

${ }^{10}$ Cf. E. R. Dodds, The Greeks and the Irrational, Berkeley: University of California Press, 1951 (E.R. Dodds, Grecy i irracjonalność, przekład J. Partyka, Bydgoszcz 2002, s. 5885). The belief that gods intervene in the life and actions of humans is nothing surprising in ancient Greeks. Especially in the classical period they were aware that everything that happens to them, both in the physical and spiritual sense, is simply a consequence of certain divine interventions, although it might have been caused by some kind of human attitude (for example, by hybris). Classic examples of this line of thinking are to be found in Aeschylus and Sophocles, but also, importantly, in Herodotus (who refers to the hybris of Xerxes and the Persians as the cause of their defeat in the battle of Salamis and other calamities). At the time of Socrates and Plato this kind of thinking had already gone quite obsolete, the Greeks having turned towards a more rational grasp of the world and its history (that is one that does not include divine interventions), particularly among the Ionian philosophers and the sophists - and the works of Thucydides might serve as an example of this change. However, this earlier kind of reasoning has not perished altogether and is still present even in the later periods despite their naturalistic turn. Moreover, it is later revived with the rebirth of Greek ancient mystical traditions and the growing influence of Eastern mysteries. 
of aesthetic sensitivity one cannot be receptive to corresponding aesthetic values and would remain blind to any aesthetic stimuli of the relevant sort).

\section{"Epopteia"}

Socrates returns to the subject of ordinations understood as a kind of perceiving and of absorbing the plain of truth and absolute values for a second time in the course of Phaedrus. Now he reminds us about the fate of a (philosopher's) soul before its first incarnation, when it beholds - accompanied by the gods - the realm of the absolute and the supernatural. This he now calls the initiation that opens the secret doors of happiness, the highest form of happiness there is, that of contemplating divine mysteries:

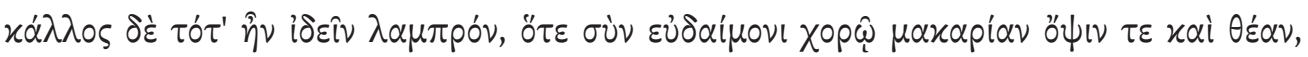

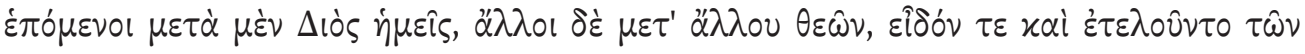

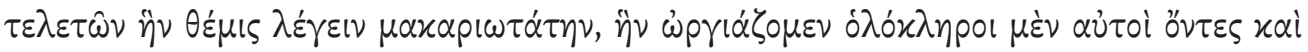

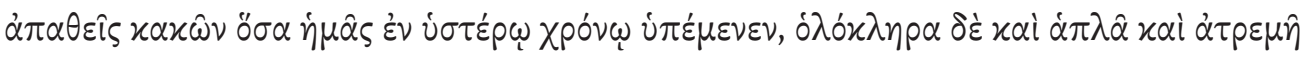

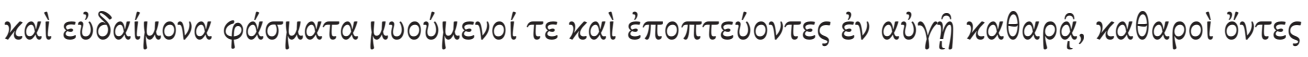

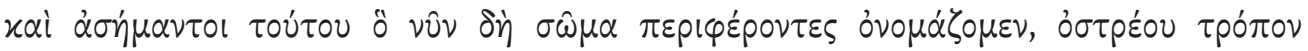

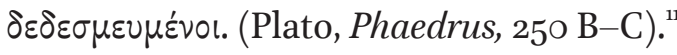

It is here that Socrates fully reveals the essence of those initiations and ordinations which he has mentioned so many times. As it turns out, they consist in contemplating the mysteries of the realm of truth and the supernatural absolute values - blessed secrets that fill those who discover them and take nourishment from them with extraordinary happiness. (Socrates has just mentioned that the sight or reminiscence of those supernatural mysteries serve as food for the soul.) This association of contemplation and happiness is important. This is exactly the happiness that people desire and seek after, usually without realizing that it lies so close, just in reach of the human soul. It suffices to exert oneself and glance into its depths, following the voice of human innate sensitivity to truth, beauty and goodness.

\footnotetext{
${ }^{11}$ Plato, Phaedrus, 250 B-C: „But at that former time they saw beauty shining in brightness, when, with a blessed company — we following in the train of Zeus, and others in that of some other god - they saw the blessed sight and vision and were initiated into that which is rightly called the most blessed of mysteries, which we celebrated in a state of perfection, when we were without experience of the evils which awaited us in the time to come, being permitted as initiates to the sight of perfect and simple and calm and happy apparitions, which we saw in the pure light, being ourselves pure and not entombed in this which we carry about with us and call the body, in which we are imprisoned like an oyster in its shell". (Trans. H. Fowler). Cf. also: Kerényi 2004, 137-139).
} 
Another aspect of those mysterious initiations of philosophers requires our attention. Socrates lays much emphasis the moral and spiritual state of souls that obtain the blessed initiation. He stresses that they need to be pure and unsullied by evil that will be brought upon them by the bodies. Spiritual and moral purity shall always remain the secret yearning of our souls, and especially of philosophers' souls. This hidden longing may serve as a motivator in the eternal pursuit of truth, moral beauty and goodness. Moreover, this yearning - indeed a somewhat mysterious one - is the seed of the unique philosophical sensitivity and as such, it is the necessary and indispensable condition of philosophical thinking and philosophical life in general. We might even say that philosophy would not even be possible without it (cf. Plato, Epistulae, VII 343 E - 344 B; see also: ibidem, 340 C).

At the end of the quoted fragment Socrates puts even more emphasis on the aberrant feeling experienced by philosophers such as himself - the feeling of being imprisoned in the body - and this enables him to illuminate his interlocutors on the crucial distinctiveness of the soul, its separation from the body and its divine character. Socrates again turns to the well-known orphic metaphor of a pearl or an oyster imprisoned in its shell. This is a way to represent the philosopher's existential condition which manifests itself particularly in the yearning towards the realm of Truth, Beauty and Goodness. Above all, this is how Socrates is able to explain the condition of the soul itself, both in the metaphysical and existential sense, and its relation to the body and to corporeality in general, as it is bound to the flesh within the complex existence of a mortal human being (cf. Plato, Phaedrus, 246 C).

This is not the first time Socrates mentions the existential and metaphysical condition. Before he began describing the peculiar procession of gods and spirits he did introduce us to souls themselves, and in an equally picturesque fashion he presented them as winged chariots with their charioteers. Gods' horses and charioteers are of the finest ancestry. In human chariots only one horse is truly noble - the other is much inferior. Wings are important in this metaphor as they represent what is the noblest and most divine part of the soul, both in humans and in gods - this is what encapsulates the most beauty, goodness and truth, it holds all the most valuable things, things that originate from the plains of truth we mentioned before. This is what nourishes the soul and makes it grow. Evil, on the contrary, as well as wickedness, cause it to wither and dwindle (cf. Plato, Phaedrus, 246 A-E). The best food for the souls are the reminiscences of the plains of truth which she regarded while following the gods. Philosophers' souls remember the most - this is why they are the noblest, they have the strongest wings, capable of raising them high in the skies. We know now that the soul's memory is its natural sensitivity which directs it towards the supernatural. 
What strikes us the most about Socrates' vision is that it is the type of nourishment that determines the condition of the soul. The proper food for the soul, one that arouses and deepens its sensitivity is that which originates from the realm of Truth. It may be claimed that the best nourishment is the world of the supernatural values. And it is not surprising that this is where any healthy soul strives to be. A similar idea is suggested by the well-known myth of the creation of man from Timaeus, although it is presented without referencing any kind of secret initiation (Plato, Timaeus, $41 \mathrm{~B}-42 \mathrm{~B}$ ). According to this myth, it is God almighty who created human souls, or, to be precise - their divine and immortal parts, the minds. They were created as almost equal to the souls of gods. Each of them was taught about the nature of the world and the laws of fate, and each was given their own star where they resided, like in a chariot. This is how the souls learned about God's plans for them. They were to be bound to a mortal body and to be confronted with all the bodily affects, firstly with sensory experiences, then with pleasure, pain and bravery. If they succeeded in conquering them and managed to live a just life, they would return to their star. Otherwise, they would have to suffer other, inferior incarnations - right until they would overcome all the bodily affects that come with each subsequent body. This is also where a form of preexistential cognition is mentioned, which allows us to speculate that certain types of knowledge that transcend the sensual level, or at least certain cognitive procedures that trigger such knowledge are given to human beings right at birth. In other words, they constitute some of our essence, they are part of our characteristic as individuals and as a species - and as such they determine our natural, species-specific behaviour. According to Plato, human natural cognitive dispositions include spiritual cognition (noesis) which may be identified with an intuitive awareness of supernatural values. It establishes our natural sensitivity, both responsive to and oriented towards spiritual values to which our other cognitive faculties such as our reason and our senses are not susceptible.

This spiritual sensitivity in its highest form may also open the human soul to mystical experiences, although only if it is ready, in an ethical, intellectual and spiritual sense.

\section{REFERENCES}

Burnet, J., ed. (1900-1907) Platonis Opera, t. I-V, Oxford.

Hermann, C. F., ed. (1921-1936) Platonis Dialogi secundum Trasylli tetralogies dispositi, t. IVI. Leipzig: Teubner.

Albert, K. (1980) Griechische Religion und Platonische Philosophie. Hamburg: Felix Meiner Verlag.

Baudy, G. J. (1986) Adonisgärten. Studien zur antiken Samensymbolik. Frankfurt am Main: Verlag Anton Hain. 
Cerri, G. (1991) Platone sociologo della comunicazione. Milano: Saggiatore.

Dodds, E. R. (2002) Grecy i irracjonalność, przeł. J. Partyka. Bydgoszcz: Homini.

Dodds, E. R. (1951) The Greeks and the Irrational. Berkeley: University of California Press.

Erler, M. (1991) Il senso delle aporie nei Dialoghi di Platone. Esercizi di avviamento al pensiero filosofico, trad. Claudio Mazzarelli. Milano: Vita e Pensiero.

Gaiser, K. (1996) L'oro della sapienza. Sulla preghiera del filosofo a conclusione del "Fedro" di Platone. Introduzione e traduzione di Giovanni Reale. Milano: Vita e Pensiero.

Głodowska, A. (2006) "Fajdros Platona, czyli między niebem a ziemią," Collectanea Philologica 9, Wydawnictwo UŁ, Łódź, 23-35.

Kerényi, K. (2004) Eleusis. Archetypowy obraz matki i córki, przeł. I. Kania. Kraków: Wydawnictwo Homini.

Szlezak, T. (1997) Czytanie Platona, przeł. P. Domański. Warszawa: Wydawnictwo IFiS PAN.

Trabattoni, F. (2005) La verita nascosta. Oralità e scrittura in Platone e nella Grecia classica. Roma: Carocci.

Vegetti, M. (1989) Nell'ombra di Theuth. Dinamiche della scrittura in Platone. Roma-Bari: Laterza.

Yunis, H. (2015) “Eros in Plato's Phaedrus and the Shape of Greek Rhetoric," Arion 3.1, 101-125. 